\title{
Reciprocal interactions between honeybees and combs in the integration of some colony functions in Apis mellifera L.*
}

\author{
H.R. Hepburn \\ Department of Zoology and Entomology, Rhodes University, Grahamstown 6140, \\ South Africa
}

(Received 11 June 1997; accepted 28 October 1997)

\begin{abstract}
Recent advances in studies of the reciprocal interactions between honeybees and their combs are reviewed. Wax secretion is age-related, varies with season, is unaffected by the queen, juvenile hormone or the corpora allata but is enhanced in swarming. Comb building is enhanced by the queen. Nest structure can be explained as a self-organization process as can the patterns of brood, honey and pollen. The comb and its contents provide gross information to the colony as to crowding and space which affect brood rearing, energy consumption and comb building. Significant chemical and physical changes occur in the wax during comb building and during its subsequent use. Comb mediates pheromonal cues for cell capping, repairs and queen cell construction, nectar forage, colony defense and colony odor. Mechanically, the combs transmit vibrational signals in the waggle dance and recruitment of new foragers. (C) Inra/ DIB/AGIB/Elsevier, Paris
\end{abstract}

honeybee / combs / pheromones / sound / self-organization

\section{INTRODUCTION}

The exquisite structure of the combs of honeybees reflects something of the complex behavior needed to have made them. But far from static, the combs constitute a dynamic system that is reciprocally interactive with honeybees. In consequence, both undergo continual changes in elaboration and organization as the cycle of the colony and its nest unfolds. As more knowledge about bees accumulates the notion of 'reciprocal interactions' between the bees and their combs becomes increasingly obvious. Sometimes these interactions are simultaneous, other times they

* In memoriam: R. Darchen

Tel.: (27) 461 318098; fax: (27) 461 24377; e-mail: zohh@warthog.ru.ac.za 
may be primarily 'bee-to-nest' or 'nestto-bee'. Unraveling these intricate patterns and processes sometimes seems intractable. However, fresh insights into old problems always renew impetus in the centuries-old quest of comprehending honeybees in a predictive way.

This review is admittedly unbalanced in several ways. There is no focus on the dual functions of comb in brood rearing and for storage, nor allusion to the problems of allocation of drone and worker cells. Nor, is the problem of maximizing reproductive output with a minimum investment in wax considered. It simply reports recent developments on 'comb-bee' interactions since this topic was last comprehensively reviewed (Hepburn, 1986). These specifically include the dynamics of comb building, the material properties of the combs, the regulation of comb building and cycle of wax secretion, and how the contents of the combs become distributed. Greater developments have occurred in areas where combs form a basis for chemical and acoustical communications and these are stressed.

\section{COMB BUILDING}

\subsection{Nest cavity}

All of the cavity-dwelling honeybees have extremely wide tolerances on the acceptability of a potential nest site in terms of volume; but the European races prefer a volume of about $40 \mathrm{~L}$ (Seeley and Morse, 1976) while the African races prefer a volume of some $20 \mathrm{~L}$ as measured directly in nature (McNally and Schneider, 1996) or in choice preference tests (Berg, 1996). In any event, the nest cavity imposes constraints and the colony is absolutely bound in three dimensions by its particular conformation. As the combs increase in number and size they must bear correspondingly larger loads of brood and stores as well as accommodate the thermal and respiratory needs of the colony.

Additional insights are to be gained about cavity filling from experimental studies of transitional hive design where the main objective is to eliminate all but the top bar of a conventional hive frame, but at the same time to avoid comb attachments to the cavity wall that interfere with beekeeping practice. Interesting results that bear on this problem come from such a study by Budathoki and Free (1986). If one regards their manipulated frame sidebars as surrogate cavity walls, then as the slope of the cavity changes so does the principle of attachment. The greater the angle of departure is from the vertical, the lesser the degree of attachment. Similarly, with greater slope, the distance from the comb base to the attachment site increases. Least comb is attached to a continually curved surface.

\subsection{Comb development}

Primed for comb construction in a new nest cavity, workers often begin to build simultaneously at several different sites. But the orientation of the bees in the festoons form a parallel, flexible scaffolding that predetermines the coordinates of further construction (Darchen, 1968). The whole process of development of the threedimensional structure can be interpreted as a self-organizing system of bee-bee and bee-comb interactions (Belic et al., 1986). This model has captured the essential features of comb construction and by-passes the need for any dependency on an intrinsic blue-print in honeybees (figure 1).

While the midwalls of neighboring combs may be far from parallel, the distances between them eventually reflect the bee space tolerances typical of the race constructing them. Analyses of these constructions show that the building toler- 

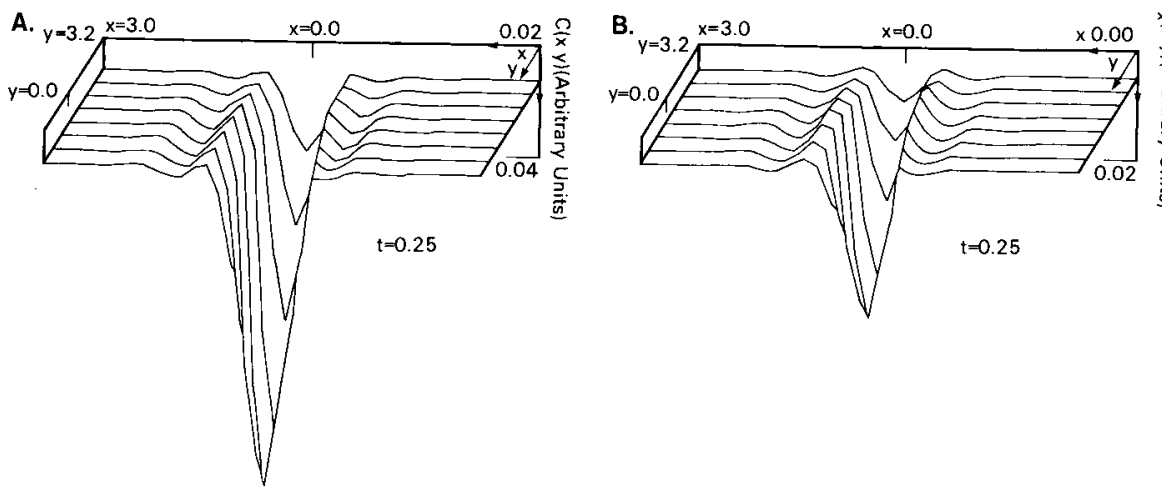

Figure 1. Mathematically-derived model of comb construction that incorporates bee-bee and bee-wax interactions. The coordinate system is such that the $\mathrm{x}$ and $\mathrm{y}$ axes lie in the ceiling plane with the z-axis pointing downwards. A: distribution of the deposited wax (z-axis with arbitrary units) on the ceiling plane of $x$ and $y$ showing a central peak of comb development and that of adjacent side combs at time $t=0.25 ; \mathrm{B}$ : the corresponding distribution of the average density of bees ( $z$-axis with arbitrary units) parallel to the $\mathrm{x} \bullet \mathrm{z}$ plane at time $t=0.25$ (after Belic et al.,

ances of honeybees are wide and that many steps in construction are independent of one another (Hepburn, 1983, 1986). However, once two or three combs have begun to be built, the relative positions of new combs have effectively been determined (figure 1). To achieve parallelism the bees adjust cell length and introduce irregular cell bases and if these manipulations are not adequate to meet their tolerances, additional combs may be inserted to this end (Hepburn and Whiffler, 1991). All that is required is the backto-back proprioception of two workers who can estimate the length of a straight line segment.

\section{MATERIAL PROPERTIES OF COMBS}

\subsection{Mechano-chemical changes}

Order of magnitude differences in the mechanical properties of wax scales and comb wax and their texture-adjusted films clearly indicate that the process of comb building involves chemical modification of the waxes (Kurstjens et al., 1985). Further analysis of the protein fraction revealed some 17 bands in the electrophoretograms, some unique to each wax (scale and comb) and others shared (Kurstjens et al., 1990). Two inferences were made from the data: two fractions common to both waxes are of similar molecular weight to other insect lipophorins and they may be gland-to-surface transport proteins. In the mastication of wax scales additional protein is added, presumably lipases, because comb has a higher monoacylglycerol content than the diaclyglyceride-richer wax scales (Davidson and Hepburn, 1986). The latter effect is to increase the degree of saturated bonds in comb thus contributing to better stiffness (Kurstjens et al., 1990).

Since lipolytic enzymes added to the wax by the bees require an aqueous medium, a source of moisture needs to be present in the wax medium. Given an aver- 
age relative humidity in a hive of about RH-50 (Simpson, 1961), moisture is available as a by-product of respiration, thermoregulation and dehydration of nectar. Also required is a means to deliver this moisture into the wax. Recently, Donhowe and Fennema (1992) demonstrated that the water vapor permeance of beeswax films is sufficient to deliver $1.7 \mathrm{~g}$ water per kg wax into the comb structure. They further pointed out that although beeswax is primarily hydrophobic, the esters, hydroxyl groups of free alcohols and the carboxyl groups of free fatty acids are hydrophilic. Physical effects of wax hydration would include matrix swelling and an increase in the diffusion coefficient of the wax (Donhowe and Fennema, 1992).

The modifications of comb performance by the presence of proteins and water can now be related to the material properties of combs as they evolve in the nest (Hepburn and Kurstjens, 1988). In the course of its development new comb wax is an isotropic plastic whose mechanical properties depend heavily on temperature. In time, generations of larvae introduce silk into the waxen structure in a random alignment to achieve equal properties in all directions. Thus, with use the comb becomes a fiber-reinforced composite material which exhibits properties entirely different from the individual components. The addition of silk greatly improves the load-carrying capacity of the combs (Hepburn and Kurstjens, 1988). Although not a theoretically ideal stiff plate structure (Nachtigall and Kresling, 1992), the mature comb is nonetheless a remarkable compromise between technical construction and the biological purposes it serves. A flow diagram for the conversion of wax scales into comb is shown in figure 2 .

Finally, some recent discoveries about comb chemistry have been made but their significance is not yet apparent. Puleo (1991) summarized the details of the minor constituents of beeswax and listed some 117 compounds derived from propolis and also commonly found in comb wax. Of these, 41 are specifically associated with wax aroma. Similar reports on compounds derived from propolis have appeared (Seifert and Haslinger, 1991; Tomas-Barberan et al., 1993). Of considerable interest is that Brand-Garnys and Sprenger (1988) analyzed the simple esters and hydrocarbons of beeswax using high resolution gas chromatography and found that 16 subspecies of $A$. mellifera could be unequivocally recognized by their chemical signatures. Circumstantial evidence suggests that some of these components may help define different dance arenas (cf below).

\subsection{Thermal properties}

Another extremely interesting aspect of the bee-comb relationship is that between a thermoregulated temperature of about $35^{\circ} \mathrm{C}$ and the workability of the wax. Over the range of temperatures encountered in different areas of the nest the amount of energy required to work the wax into comb at $35^{\circ} \mathrm{C}$ is half that at $25^{\circ} \mathrm{C}$ which is an energetic savings (Hepburn, 1986). At new comb building sites, often away from the main cluster especially as the nest expands to several combs, the festoons provide some of their own ambience of warmth at about $35^{\circ} \mathrm{C}$ because the temperature difference between a festoon and the main cluster may be some $5^{\circ} \mathrm{C}$ (Hepburn and Muller, 1988).

The thermal properties of combs in relation to colonial heat balance, part of the entire energetic equation of a colony, were explored by Southwick (1985). He measured the thermal conductivity of isolated comb and found that while the combs provide insulation, the clustering behavior of the bees actually increases the insulat- 


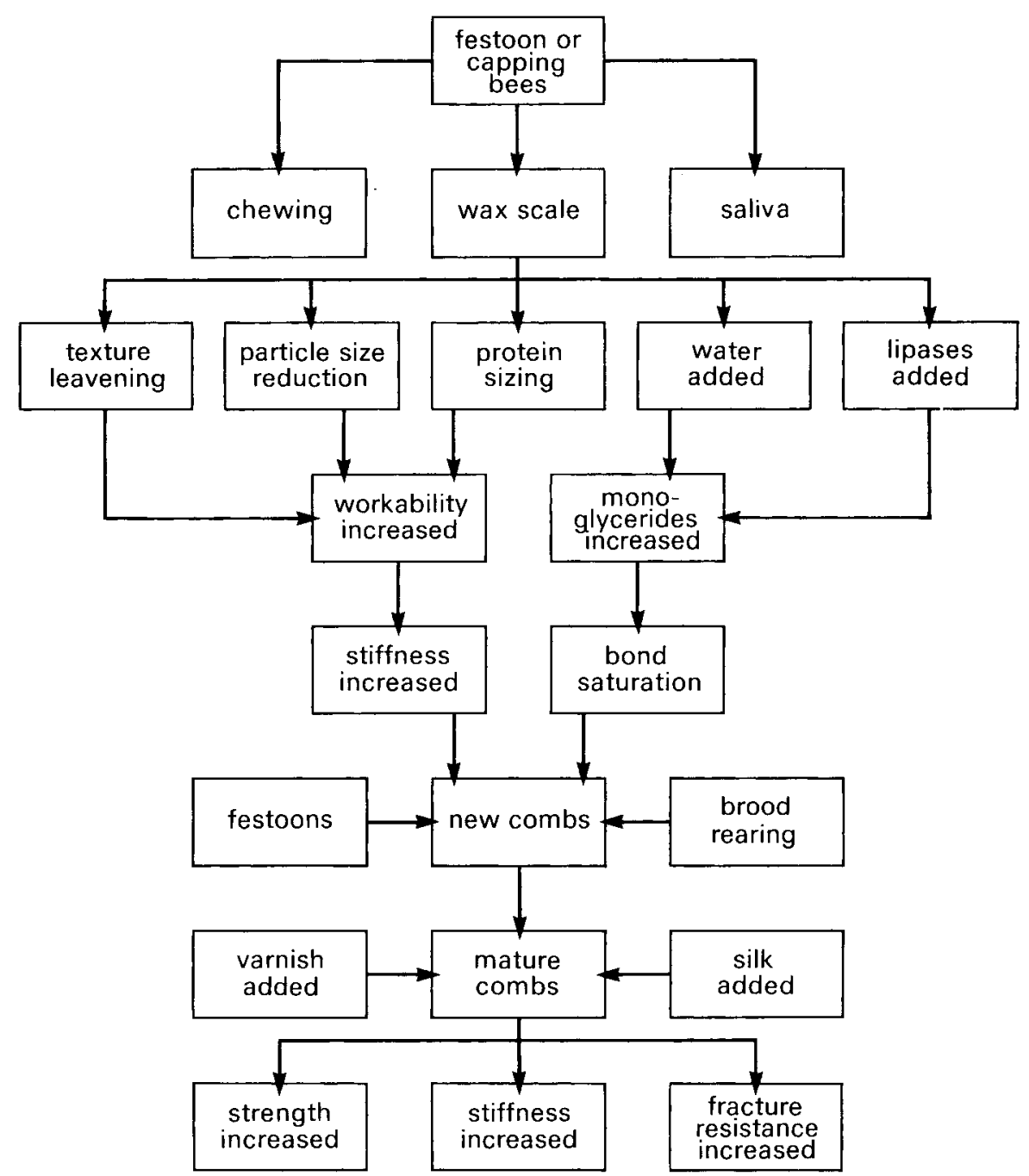

Figure 2. Simplified flow diagram for the conversion of newly secreted wax scales into new comb followed by the events associated with the maturation and use of the combs.

ing effectiveness of the combs. When there is a compact layer of bees on the combs, conductivity can be reduced by an order of magnitude. Given the conductivity of wax combs and bees clustered on and between them, insulation of the combs is the combined effect of combs and the behavior of the bees themselves (Southwick, 1985).

\section{REGULATION OF COMB BUILDING}

\subsection{Seasonality}

It is well established experimentally that newly settled swarms are prodigious 
comb builders (Lee and Winston, 1985; Hepburn, 1986), but in a temporo-spatial framework, comb building only reaches parity with other wax working (capping and repairing) at the height of the colony growth cycle (Muller and Hepburn, 1992). Comb building is conducted in different areas of the nest by many individuals, some clustered in festoons others not, while other wax works are often the efforts of individual bees (Lindauer, 1952). Changing ratios of what work and where it is carried out can be assessed by following the raw wax in a colony with the changing seasons.

Muller and Hepburn (1992) found that in the course of a year as much wax is found in festoon bees as in bees elsewhere among the combs but seasonal pictures are quite different (figure 3). It appears that wax-bearing bees can be found in the right places at the appropriate times. The wax bees shift from one area of the nest to another, for example, with heavy nectar flows for honey cell capping or to areas requiring brood capping. This ensures a close correspondence between comb area 'needs' and the presence of bees with wax scales. Although not all would agree (Fergusson and Winston, 1988) the distribution of these wax bees is largely predicated on an underlying age-based cycle of glandular secretion (Hepburn et al., 1991).

\subsection{The effects of storage space}

That strong nectar flows fuel comb building is an old principle of beekeeping and a proposed explanation for the relationship was formulated by Butler (1954). He argued that the greater the influx of nectar into the colony, the longer the house bees must retain it. This, of course, requires the right combination of available storage space and ratio of foragers to house bees. Serving as distended reservoirs over time, these bees assimilate some of the nectar sugar and become stimulated to secrete wax. This sensible idea has proven far easier to appreciate than to test. Using queenright colonies in which comb available for nectar storage was experimentally reduced or entirely eliminated, a correlation between engorgement of the honey stomach and wax secretion was obtained (Hepburn and Magnuson, 1988).

This experiment did not distinguish between physical distension of the honey stomach and the time such a bee might spend in trying to disgorge and store the nectar. Nonetheless the observation is indirectly supported by experiments in which either the deprivation of combs (Fergusson and Winston, 1988) or lack of sufficient storage space (Seeley, 1995) both lead to increased foraging, accelerated wax secretion and, ultimately, comb building. Collectively, the experimental data lead to a simple feedback system: forager dancing effectively recruits more nectar-foragers; when this nectar is difficult to off-load, a special tremble or stop dance is performed which inhibits further recruitment (Seeley, 1992; Nieh, 1993).

During comb building there are concomitant changes in population size, density, nectar and pollen influx which reflect honeybee-comb interactions. Of these, Harbo (1988) examined the relationship between colony size, brood production and combs for colonies that were totally equalized. He found that those colonies which had produced the largest amount of comb had also produced the largest number of brood and adult workers. To separate queen from comb effects, a second experiment was performed using large and small combs as the variables of interest. Comb effects were significant (queens not) and small combs resulted in reduced brood production.

But there is more to a colony in a cavity, and the variables richer than had been assessed. Harbo (1993) extended his findings to assess the effects of nest cavity 


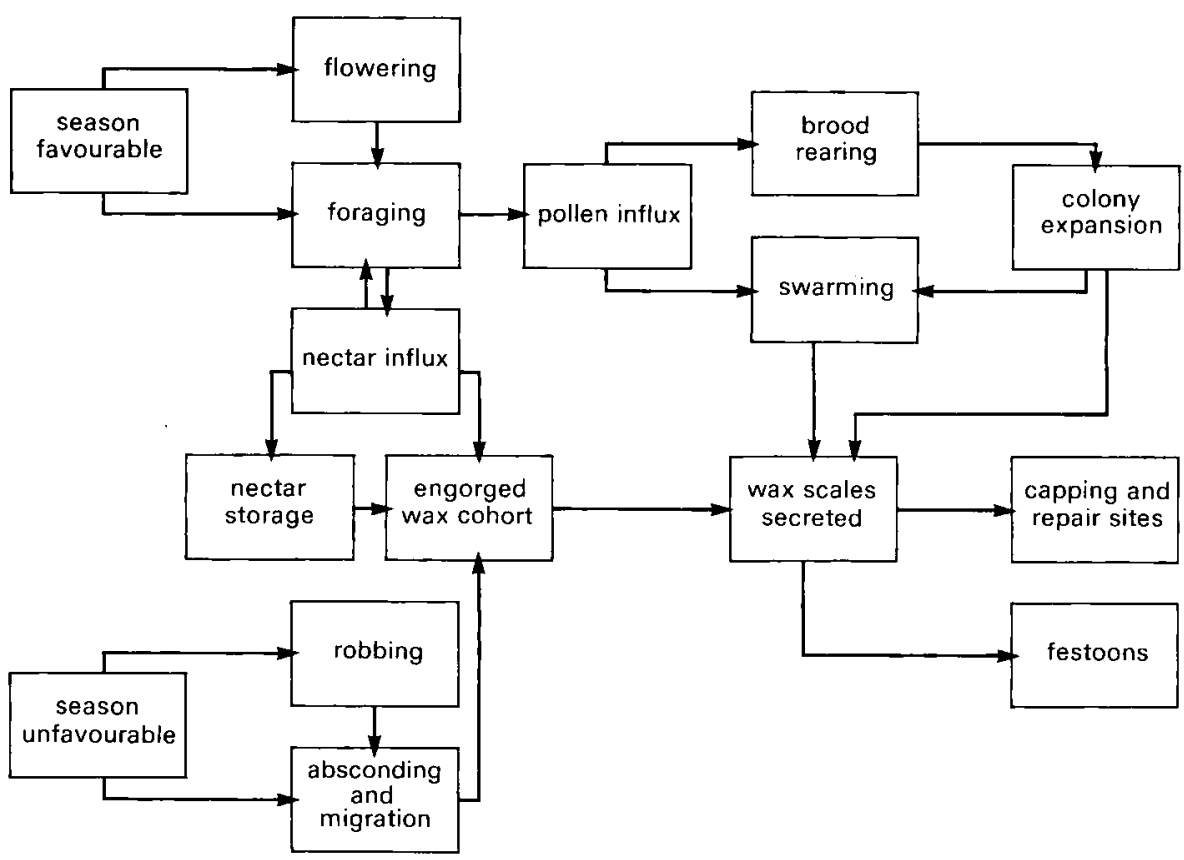

Figure 3. Simplified flow diagram for the stimulation of wax secretion in $A$. mellifera. The favourable season sequence should apply to all mellifera subspecies; the unfavorable season sequence applies to the mellifera subspecies of Africa.

(hive) volume on growth and productivity by adjusting the population density against volume. In winter, crowded bees consumed less honey per bee and reared less brood than the less crowded colonies. During the flows of spring through autumn, the crowded colonies produced more honey but less brood than the less crowded ones. In another experiment, comb effects were tested against space effects. Both affected brood rearing and honey production. Colonies with combless extra space produced less honey and more brood than those with the same amount of comb but less space (Harbo, 1993). These results complement those of Taranov (1959) and Szabo (1977) who had shown that brood production and comb construction are not competitive activities: the exclusion of one activity does not accelerate the other.

\subsection{Nectar and pollen}

With an age-related division of labor mechanism for wax established, one must consider the development of whole colonies in a seasonal and interseasonal context. It is a common observation that the comb is built in response to colony need especially given a strong nectar flow. For example, Seeley (1995) reports the results of some interesting and pertinent experiments. In observation hives in which the manipulated variable was the amount of nectar on hand, comb building was initiated during an artificial flow when the honey storage cells were nearly full. Duration of the comb building activity was a function of both intensity and duration of flow. This routine principle of commer- 
cial beekeeping has now acquired additional experimental support (Seeley, 1995).

The fundamental importance of pollen as a source of protein for wax secretion has long been established [cf. references in Hepburn (1986)]. However, bee-comb interactions with respect to pollen have been little studied. Camazine (1993) reported on a series of experiments to elucidate how a colony might regulate pollen forage: 1) direct assessment of pollen stocks by individual foragers; or 2) indirectly in which one group, house bees, might make such a determination and somehow inform pollen foragers accordingly. In one experiment pollen supplementation led to a reduction in pollen forage; another showed that foragers do not require direct contact with pollen stores to adjust their foraging. Subsequent experiments to assess the role of pollen odor were conflated by brood odor. So while the basic approach remains viable, this problem must be solved in future analyses.

\subsection{The queen}

Other indirect evidence for the Butler mechanism comes from studies of swarming and absconding. Comparisons of workers from natural swarms, heavily engorged with nectar, with those of settled colonies demonstrated that more swarm bees bore wax (not amount of wax per bee) than their settled counterparts. It also transpired that there were no measurable differences in the pheromonal bouquets of the mandibular glands of the relevant queens (a decade ago the general explanatory panacea for queen-worker interactions) which cast doubt on their efficacy in stimulating wax secretion (Hepburn and Whiffler, 1988). Likewise, in absconding colonies, just as many bees bore wax when headed by free-running queens as those lacking physical access to her presence because of a cage of double-gauze (Hepburn, 1988).
Thus, the possible importance of the queen for wax secretion needed to be addressed systematically. This was achieved in a series of experiments employing various queen states: queenless, mated and virgin queens as well as dead ones to obtain a pheromonal spectrum. Experimental manipulations included surgical ablation and occlusion of the mandibular and tergal abdominal glands, respectively, and the use of division boards to restrict the access of divided colonies to different parts of the queen's body. At the end of the trials the amount of wax recoverable from festoon bees did not significantly differ: the physical and chemical queen had no measurable effect on wax secretion but did on comb building (Whiffler and Hepburn, 1991a). That as much as half of the standing stock of wax scales is distributed among non-festoon bees was only discovered somewhat later (Muller and Hepburn, 1992).

\subsection{The cycle of wax secretion}

These experiments had been performed in different seasons with varying field conditions as well as races of bees, so more controlled information on wax secretion was needed. First, using bees of precisely known age, it was shown that secretion was a continuous process, there was no diel rhythm (Hepburn and Muller, 1988). This led to a 2-year study of wax secretion in queenright colonies from which the wax scales of some 11000 bees were recovered and weighed. Wax secretion was parabolically cyclic and related to age: secretion begins at about 3 days after emergence, reaches a peak between 9 and 12 days and wanes between 18 and 21 days (Hepburn et al., 1991). This then filled the gap between the histological observations of Rösch (1927) and the physiology of the secretory cycles. 
The cyclical changes of cellular organelles and the chemical composition of beeswax precursors found in the haemolymph (Francis et al., 1989) and gland tissues closely coincide with measured, age-related rates of wax secretion (Hepburn et al., 1991). Attempts to alter this cycle by increasing or decreasing the amounts of juvenile hormone and or the addition or removal of the corpora allata had no measurable effect on the onset of wax secretion, its duration or the amount of wax actually produced for this age cohort (Muller and Hepburn, 1994). Thus wax secretion is one of the division of labor activities for a certain age cohort, but may vary with the proportions of subordinate and dominant workers (Hillesheim et al., 1989). This coincidence of physiology and behavior parallels other polyethisms such as colony defense (Whiffler et al., 1988; Breed et al., 1990) and brood care (Liu, 1989; Crailsheim and Stolberg, 1989): all are predictable activities correlated with age and cycles of glandular function.

\section{DISTRIBUTION OF COMB CONTENTS}

It has been tacitly assumed for centuries that the patterns observable in the arrangement of nest contents is in some mysterious way 'in the nature of bees'. However, the casual observation that pollen and honey are regularly deposited in empty cells within the brood area during the day, only to be removed to their 'proper' places during the night, led to an especially seminal paper on pattern formation in comb use in honeybees by Camazine (1991). He conducted experiments to validate one of two mutually exclusive hypotheses: 1) a blueprint or template in which patterns develop in some pre-ordained and specified way intrinsic to bees; or 2) a selforganization mechanism in which pattern emerges spontaneously from the dynamic interactions among the processes of placing and then displacing the relevant nest elements.

In a series of classically simple observations and experiments Camazine (1991) noted that the brood pattern is initiated by the laying habits of the queen who must take into account the presence of nearby brood and, perhaps, the comb boundaries. This given, the queen lays eggs and the bees deposit both nectar and pollen haphazardly among the combs in the first instance. Possibly informed by the presence of young nurse bees, the queen does not lay eggs outside of the nascent brood area but continually searches for empty cells near other eggs or brood. Cells in the brood area filled with honey or pollen are preferentially emptied of their contents. This is experimentally shown by a frequency distribution for cell emptying from the brood area. It is a function of distance to the nearest brood cell. Brood cells so emptied of nectar and pollen are then found by the queen who lays in them, and so the pattern develops (figure 4).

Camazine (1991) and colleagues then proceeded to develop a computer simulation model to establish pattern-forming rules as estimated from the actual experiments. Using the empirical events from the observation hive as the parameter values, he was able to reveal the interacting processes that contribute to pattern formation. The simulation also produced the final pattern observed in the observation hive and confirms the interpretation of pattern formation. The model and the selforganization hypothesis appear extremely robust and parsimonious. This idea has been further analyzed mathematically by Jenkins et al. (1992) who derived rate constants for the removal and redeposition of honey and pollen in order to achieve their characteristic bands and positions above the brood areas (figure 4). 

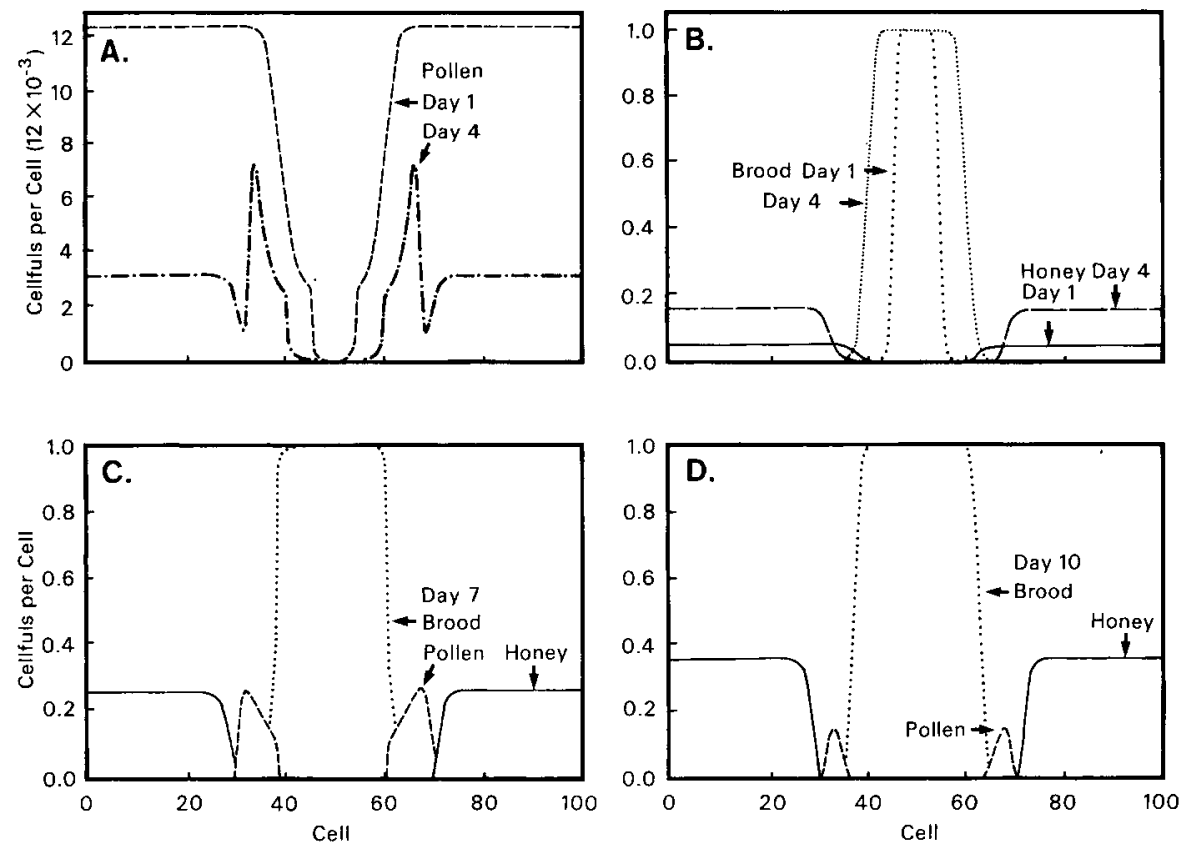

Figure 4. Sequence of events in the self-organization model for the formation of brood, pollen and honey patterns that occur on insertion of a drawn frame into an observation hive. (a) Pollen distribution when input is low; concentration of pollen initially increases at the periphery but then decreases and is low everywhere. (b) Over the first few days the brood area has expanded with an increase in honey at the periphery. (In this model there was a 3-day pollen burst over days 5-7.) The interface zone between honey and pollen consists of empty cells due to low level of pollen. (c) By day 7 the pollen band has developed rapidly and a typical pattern for brood, pollen and honey has formed. Honey concentration is increasing at the periphery and the brood area is expanding. (d) At the end of day 10 the pattern is intact but the pollen band is decreasing but more slowly than formed. Equilibrium is reached when the brood is surrounded by honey and pollen and the queens can find no empty cells in which to lay (after Camazine, 1991; Jenkins et al., 1992).

\section{COMBS AND COMMUNICATION}

\subsection{Queen cells}

While there is substantial evidence that wax secretion is not influenced by the status or quality of the queen, comb building and queen cell construction are different matters. The construction of queen cells is contextually quite different from that of combs, but in both the role of the queen is significant. There are two important observations to consider. First, Boch (1979) showed that when a closed queen cell was given to a small queenless colony, further queen cell construction was greatly reduced in comparison to control colonies. Second, Fell and Morse (1984) demonstrated a rapid decline in the number of new queen cells built following construction of those cells found on the first day after queen loss.

Unfortunately, yet other experiments which implied a pheromonal role for the 
queen in emergency queen cell construction led to conflicting results [cf. discussion and references in Whiffler and Hepburn (1991a)]. To resolve these problems, these authors measured the effects of queen state on the inhibition of emergency queen cell construction exactly as had been carried out for comb building using freerunning, caged and division board queens (Whiffler and Hepburn, 1991b). Greatest inhibition of queen cells was achieved in colonies with free-running queens and least in queenless ones. For the former, queen inhibition diminished with increasing impairment of pheromonal function through removal of the mandibular glands and occlusion of the abdominal tergite glands. Nonetheless, there was marked variation within and between treatment groups just as had been found in other studies (Fell and Morse, 1984; Winston et al., 1989; Kaminski et al., 1990) and for which there was no obvious explanation.

It is now evident that the inhibition of emergency queen cell construction is not an all-or-nothing phenomenon but is effected as a series of graded responses (Hepburn et al., 1988; Engels et al., 1993). All of the experimental data on this problem can now be accommodated within an interpretation that the relevant pheromonal scent of the queen can be recovered not only from the site of secretion but from all parts of her body, including the legs (Winston et al., 1989; Slessor et al., 1990; Engels et al., 1993). In this view inhibition of emergency queen cell construction is primarily mediated by pheromones of the mandibular gland spread over the whole surface of the queen as originally supposed by Butler (1954), as well as by contributions from the tarsal and abdominal tergite glands (Lensky and Cassier, 1992).

There is also an element of the comb involved in the inhibition of swarming queen cell construction. Lensky and
Slabeski (1981) added footprint (or tarsal gland) pheromone to the inhibitory effect. They demonstrated that in populous and crowded queenright colonies that swarm cells are constructed at the bottom edges of the combs because the queen does not move to the edges of the nest. Hence comb edges lack footprint pheromone. When they placed a combination of mandibular gland and tarsal gland extracts on the bottom edges of the combs swarm queen cell construction was inhibited. Similarly, if a fresh comb surface is provided, unmarked by pheromones of the queen, queen cell construction will proceed. Under emergency conditions, the majority of queen cells are constructed in the center of the brood area based on cells containing eggs or larvae (Lensky, pers. comm.). This also explains the fact that there is no measurable change in the pheromonal bouquet of the mandibular glands of queens whose colonies are preparing to swarm (Seeley and Fell, 1981). In this case comb wax is the intermediate in the transmission of the inhibitory pheromones.

In this discussion the chemical aspects of the queens' pheromones have been emphasized. Due to the abundance and complexity of these bouquets, the significance of individual and/or permutations of compounds has not been precisely determined. It should also be remembered that the control of queen cup and swarming cell construction is complex and depends on both ecological (temperature, availability of nectar) and biological factors such as worker density (Lensky and Cassier, 1992).

\subsection{Cell capping and repairs}

In studies on the chemical ecology of brood pheromones, Le Conte et al. (1990) demonstrated that a series of only four methyl esters (part of a normal pheromonal cocktail produced by queens, 
workers and drones) is sufficient to induce the capping of cells containing mature larvae. These compounds are multifunctional and differing ratios modulate the feeding behavior of worker bees or lead to cell capping (Trouiller et al., 1991; Trouiller, 1993; Le Conte et al., 1995a). In the case of queen cells, the developmental progress of the larvae is constantly signaled by the ester ratios. This was confirmed by using substitutes doped with the pheromones (Le Conte et al., 1995b). Following capping of the doped dummy queens their continued acceptance in the colony depended on their ability to emit the correct esters. Presumably, this also explains the inhibition of queen cell construction in the experiment of Boch (1979).

There remains the vexing problem of signal specificity. At any given time a substantial portion of the larval population could be emitting capping signals. These might only indicate that there is an area of brood comb requiring the attention of house bees to perform capping. Goetz and Koeniger (1992) reasoned that if capping depends entirely on pheromones then brood cells should be capped according to larval age. Alternatively if capping can be advanced by decreasing cell length, or delayed by increasing it, then larval size in relation to cell depth could be important in triggering capping behavior. They experimentally modified larval distance from the cell opening by artificially increasing or decreasing cell depth. Their results seemed to show that the worker bees responded according to the distance parameter and not age (Goetz and Koeniger, 1992).

Subsequently, Le Conte et al. (1994) revisited this problem. Having previously shown that workers will cap cells containing paraffin dummies doped with the ester blend of old larvae (Le Conte et al., 1990) they then proceeded to a more thorough analysis of pheromonal (ester) concentration, the position of the larvae in the cells, the effects of ester blends on worker capping and then as pertains to queen cells. Their results showed that capping activity depended on ester concentrations which suggest that the presence of a larva is pheromonally mediated. The position of the larva influences capping, possibly by affecting the head-space of pheromone available to stimulate workers. In tests of blend discrimination, dummies doped with the young larval blend (ethyl esters) were not capped, dummies with the old larval blend (methyl esters) induced capping.

Le Conte et al. (1994) conducted further tests on queen cell construction and capping in dequeened colonies in which the effects of both larval position and pheromonal blend were measured. Greatest queen cell construction occurred when dummies were doped with the young larval blend and positioned at the bottom of the cells. Thus, for both the capping of worker larvae and queen cell construction the results of Le Conte et al. (1994) indicate that workers can and do discriminate between young and old larvae, the bouquets of their respective ester blends and the positions of the larvae in their cells. The combined results of Goetz and Koeniger (1992) and those of Le Conte et al. $(1990,1994)$ are not mutually exclusive in principle; rather, more experimentation is needed to establish their possible interrelationships.

The honeybee approach to obstacles and necessary repairs to the combs have been thoroughly documented by Darchen (1968; and references therein). An interesting idea that Darchen had but apparently never tested, was that once completed cells had been put into use they were primed or painted with some propolis- or varnish-like material which inhibited bees from further modifying them. If a piece of comb is excised experimentally, the bees soon repair it, the interpretation being that the inhibitory substance was removed. Chauvin (1992) recently 
reported that such a propolis-like material occurs on the outer edges of cells and only there. So here too a chemical cue is provided by the combs which direct the activities of worker bees.

\subsection{Colony odor}

Another way in which the bees and their combs interact is in the generation and recognition of a colony odor, an idea from a previous century brought to fruition by Kalmus and Ribbands (1952). A few years later Juska (1978) contributed further to the identification of nest-mate recognition cues by demonstrating that footprint or trail scents are deposited on the combs from the tarsal glands as the queen moves about. That the scent persists for some time led to the conclusion that it is an additional way of communicating queenrightness. That the combs might acquire and then dispense the chemical signature of the queen is a parsimonious way of producing a general signal. Here, as in inhibition of queen cell construction on the bottom edges of the comb, the integrative signal is mediated through the combs.

The idea of colony odor was pursued with this view by Breed et al. (1988a) who discovered that colony odor (their 'hive effect') is acquired very soon after adult eclosion and, in cross-fostering experiments, the effect of colony odor completely masked genetic differences between the bees. The mechanism for this result was pursued in a second work (Breed et al., 1988b) when comb-conditioned bees were introduced to other related but comb-naive bees, the former were rejected; when the receiving bees were comb-conditioned to the same comb source as the introduced bees the latter were accepted. Whatever the origin of the bees, bees conditioned to the same comb source were more readily acceptable than bees between comb-type transfers.
Although there was no specific control for individual bee odors as such in the Breed experiments, it is reasonable to assume that they would have been overridden when different bees conditioned to the same comb source were found to be mutually acceptable. It is pertinent to recall here that Michelsen et al. (1989) always had to 'condition' their mechanical dancing bees to the hive odor of the test colony in order to stave off attacks on the motorized dancers. Because beeswax is a chemical potpourri, Breed et al. (1988b) repeated the work with a neutral paraffin wax to which scent was added or not and the same kinds of results were obtained as had been with the beeswax.

It remains uncertain, of course, whether the observed effects derive from genetic differences in chemistry of comb source and/or the possible adsorption of environmental odors onto the waxes. The two possibilities are certainly not mutually exclusive. A common mechanism could well be the interaction between shared pools of adsorbed chemical volatiles from the epicuticle of the bee as well as the comb. This kind of mechanism would explain how flower volatiles that change with changing plant forage become incorporated into the colony system of changing colony odor.

Comb wax mediates other forms of honeybee behavior as well. For example, Fergusson and Free (1981) found that the odor of comb alone was sufficient stimulus for workers to release scent from the Nasanov gland, a common source of cluster-inducing pheromone. This is consistent with the fact that honeybees prefer old combs to new ones, possibly because they are dosed with footprint pheromone (Free, 1987). Comb volatiles also stimulate increased nectar foraging (Rinderer and Hagstad, 1984; and references therein), but bioassays of oxygenated comb volatiles were equivocal (Blum et al., 1988). A final case is that colonies given 
large amounts of empty comb attack targets twice as fast and often as colonies with little empty comb (Collins and Rinderer, 1985). Presumably, a surfeit of comb volatiles signals a shortage of reserves and the advantage of protecting them against predators/robbers.

\subsection{Communication of sounds}

Signals or cues arising from the combs include mechanical as well as chemical information. Indeed, following the discovery of the dance language, its mode of actual transmission long remained enigmatic. When potential recruits attend a dancing forager, they periodically emit vibrations against the combs which elicit a response from the dancer to give the emitter a sample of her nectar (Michelsen et al., 1986a; Sandeman et al., 1996). Similar vibrations, the tremble or stop dance, are made by returning foragers who have difficulty in off-loading nectar to house bees. The signal here may be used as a negative feedback way of reducing further forager recruitment (Seeley, 1992; Kirchner, 1993; Nieh, 1993) and/or as a means of recruiting more nectar-receiver bees (Seeley, 1992). Finally, queen piping is mediated through vibration of the combs (Michelsen et al., 1986b). This and the wing vibrations of dancers are perceived by Johnston's organ.

Other bee-comb interactions of a reciprocal nature involve the transmission of vibrations (sounds) for communication. One of the events that occurs among bees tending a dancing forager is that periodically a worker presses her thorax down on the comb to vibrate it. This often elicits a response from the dancer to give the emitter a sample of nectar (Michelsen et al., 1986a). The tremble or stop dance (mentioned previously) works acoustically in the same way (Kirchner, 1993). A third example is that of queen piping in which the quacking element emitted by virgin queens still in their cells is transmitted through the wax (Michelsen et al., 1986b). In all of these examples, transmission of vibrations or sounds through a medium depends on the density, elasticity and temperature of the substrate. For practical purposes of the honeybee nest, temperature and density can be taken as constants, so that the greater the stiffness, the higher the speed of transmission. Because sound intensity decreases with the density of the medium and with distance, an essentially anhydrous, low density wax is the ideal solid biological medium for sound transmission.

Kirchner (1993) indicated some important differences in communication by sounds and pheromones. Vibrational signals allow for the speedier transmission of a signal, a temporal coding element, and localization of the message through rapid attenuation of the signal. Pheromones and other chemical signals are pervasive in distribution and because they follow the laws of diffusion there is a long time constant for the life of the signal (Kirchner, 1993). A perfect example of this effect lies in colony odor and the intranest transmission of queenrightness. Naumann et al. (1992) have recently shown that some of the queen's mandibular gland pheromonal components secreted on her surface are acquired by workers of the retinue. Workers having contact with retinue bees acquire the signal themselves. However the signal is also spread in footprints from the passage of the queen and workers onto the combs in which it diffuses and is slowly but eventually lost from the system (Naumann et al., 1992).

\subsection{The waggle dance}

Having seen that the delivery of forage from the field and the further recruitment of foragers are associated with the trans- 
mission of sound through the comb, one can ask if there are specific sites for waggle dances. Tautz (1996) discovered that foragers that danced on empty areas of comb recruited three times as many dance followers as bees that danced on areas of capped brood. Clearly the recruitment process could be enhanced if some particular site on the comb was mutually recognizable to both dancers and dance followers. Indeed, dancing bees are commonly found on the lower comb near the entrance of observation hives (Tautz, 1996).

The existence of specific dance sites on combs was very recently demonstrated by Tautz and Lindauer (1997) in a most elegant way with a two-frame observation hive modified to have the entrance half way up the side. After the bees were trained to a non-scented sugar solution in a feeder nearby, the location of dancing bees was noted for several days. Foragers were then marked and allowed to visit the feeders and return and dance in the hive. After a while the feeders were closed and all of the bees were shaken out of the hive and the positions of the two combs switched: upper comb became bottom comb and vice-versa. The bees were then allowed back into the hive, the feeders reopened and the sites of the dancers recorded. All of the dances performed by all 20 of the marked dancers on the combs were recorded before and after switching the comb positions during seven such exchanges in subsequent days. In the total series of seven such comb switches in nearly $90 \%$ of 365 dance episodes, the dancers went to that site on the specific comb on which the dance had first been established, and irrespective of the position of the comb in the hive.

Tautz and Lindauer (1997) considered the possibility of the bees using spatial cues but noted that after combs were switched the bees also walked over the combs until they located the site of the first dance before recommencing dancing. They suggested that the rediscovery of a specific dance site would be most parsimoniously explained by a chemical marker (footprint pheromone) that would allow site reinforcement throughout the day but which would fade at night thus allowing the location of a dance site to change with changing conditions in the nest. By the same token, many of the recently discovered volatiles (cf. mechano-chemical changes above) could serve as cues for dance recruits, if they too seek the same dance site after comb switching. This could hold important implications for the analysis of patriline performance in the division of labor.

\section{CONCLUDING REMARKS}

The material properties of the comb provide both the structure necessary to accommodate the colony as well as a multi-faceted medium for chemical and mechanical communication. Through their manipulation of wax and then comb, the bees are provided with a system of cues of varying time constants which in turn modify their behavior. In this context, thermoregulation has been evolutionarily crucial in obtaining the best performance of the comb materials and also the enzyme systems of the bees themselves. At the same time, new discoveries of the unique chemical signatures in the waxes of different subspecies and the roles of chemicals in queen cell construction, cell capping and the waggle dance of honeybees may have opened a Pandora's box of unexpected factorial complexity.

Nonetheless, we have progressed far enough to see that virtually the whole of the comb building process and the patterns that emerge from its use can both be explained parsimoniously and predictively by self-organization. This at least eliminates having to impose demands on the 
neurophysiological capacity or even the genome of honeybees for which there is no evidence. Honeybee society operates in three physical dimensions which vary with the activities of the bees. The entire system is in a constant state of flux in a fourth dimension, time. This is particularly evident in the many reciprocal interactions between bees and their combs as both are born, grow and mature. Further analysis of this $n$-dimensionality might well profit from the mathematical power of virtual reality techniques.

\section{ACKNOWLEDGEMENTS}

I thank J.R. Harbo, Y. Le Conte, Y. Lensky and W.J. Muller for kindly reviewing this work in manuscript form.

\section{Résumé - Interactions réciproques entre les abeilles mellifères et les rayons dans l'intégration de certaines fonctions de la colonie chez Apis mellifera $\mathbf{L}$. Cet} article résume les progrès récents dans l'étude des interactions réciproques entre les abeilles mellifères et leurs rayons dans la mesure où elles concernent l'intégration des fonctions de la colonie. Le choix du volume de la cavité du nid varie d'une race à l'autre, mais une fois les abeilles installées, la construction des rayons qui s'ensuit peut être considérée comme un «processus d'autoorganisation » (figure 1), dans lequel les dimensions de la construction et les écarts admissibles peuvent simplement découler de la proprioception des abeilles en position dos-à-dos.

Au cours de la construction des rayons, les écailles de cire subissent des modifications physiques et chimiques par addition d'enzymes, qui changent les liaisons chimiques et renforcent ainsi les rayons (figure 2). Dans le nid terminé la présence combinée des abeilles et des rayons conduit à une isolation thermique plus grande que celle fournie par chacune des parties.

La construction des rayons est régulée par la saison. Les abeilles cirières sont présentes dans tout le nid et pas seulement dans les chaines cirières. Les interactions nid-abeille qui affectent la construction comprennent le volume de la cavité, l'espace disponible pour le stockage, la taille de la population, l'élevage du couvain et le flux de nectar (figure 3).

Une plus grande tendance à la construction est associée à la présence d'une reine et existe aussi pendant l'essaimage et la désertion. La secrétion de cire proprement dite est un cycle lié à l'âge au sein de la division du travail et n'est pas affectée par la reine.

La façon la plus économe d'expliquer la répartition de l'utilisation des rayons entre miel, pollen et nid à couvain est de considérer qu'il s'agit d'un processus d'autoorganisation, qui ne présuppose aucun plan d'ensemble dans le cerveau de l'abeille. Le processus a été modélisé mathématiquement à partir de données réelles et s'est révélé avoir une valeur prédictive reposant sur quelques règles simples (figure 4).

Les rayons jouent un rôle très particulier dans la communication au sein de la colonie. La présence de phéromones royales influe sur le déclenchement de la construction de cellules royales, sur le moment et le lieu où elles vont être construites. De la même façon, l'operculation du couvain semble être commandée par la combinaison d'une phéromone de couvain et de variables physiques telles que le rapport entre la taille de la larve et celle de la cellule. Le travail de réparation des rayons est stimulé par l'absence d'une substance inhibitrice sur les bords des cellules. L'odeur de la colonie est communiquée par la cire des rayons et influence également la défense de la colonie. Que le « plancher de danse » semble être défini chimiquement est une découverte d'un grand intérêt. 
On a montré récemment que les rayons faisaient partie intégrante de la communication sonore par les vibrations, qui sont essentielles pour le recrutement des butineuses lors de la danse frétillante. De la même façon, le chant des reines agit par transmission des vibrations par le rayon. La cire est un milieu idéal et elle permet la transmission rapide de messages codés. Par ailleurs les phéromones obéissent aux lois de la diffusion avec une constante de temps longue.

Il existe entre les abeilles et leurs nids tout un ensemble d'interactions réciproques qui varient dans le temps plus ou moins rapidement. Puisqu'il devient de plus en plus difficile de suivre simultanément l'action des variables connues, nous pourrions tirer profit à l'avenir des techniques mathématiques, utilisées dans la construction des « réalités virtuelles », pour étudier les abeilles. (c) Inra/DIB/ AGIB/Elsevier, Paris

\section{Apis mellifera / auto-organisation / rayon / phéromone / communication sonore}

\section{Zusammenfassung - Die Rolle wech- selseitiger Beziehungen zwischen Honigbienen und Waben bei der Inte- gration einiger Koloniefunktionen von} Apis mellifera. Dieser Artikel faßt neue Erkenntnisse über die wechselseitigen Beziehungen zwischen Honigbienen und ihren Waben zusammen, soweit diese für die Integration der Koloniefunktionen von Bedeutung sind. Verschiedene Bienenrassen unterscheiden sich in der Auswahl der Nisthöhlen. Sobald die Bienen sich niedergelassen haben, kann das darauffolgende Bauverhalten als ein selbstorganisierender Prozess verstanden werden (figure 1), bei dem die Baumaße und die dabei eingehaltenen Toleranzen in einfacher Weise von der Propriorezeption von Bienen in Rücken - an Rücken - Position abgeleitet werden kann.
Während des Wabenbaus werden die Wachsplättchen physikalisch und chemisch durch Zufügen von Enzymen modifiziert. Diese verändern die chemischen Bindungen und versteifen hierdurch die Waben (figure 2). In dem fertigen Nestbau bewirken die Bienen in Verbindung mit den Waben eine höhere thermische Isolation als jede der Komponenten für sich.

Der Wabenbau unterliegt einer jahreszeitlichen Steuerung. Hierbei treten wachserzeugende Bienen nicht nur bei den Baubienen, sondern überall im Nest auf. Die Ausscheidung von Wachs ist ein altersabhängiger Prozess innerhalb des Musters temporärer Arbeitsteilung. Dieser wird von der Anwesenheit einer Königin nicht beeinflusst.

Einflußgrößen, die vom Nest auf das Bauverhalten der Bienen wirken, umfassen das Volumen der Nisthöhle, den vorhandenen Speicherplatz, die Populationsgröße, die Brutaufzucht und den Nektarfluss (figure 3). Die Neigung zum Wabenbau wird durch die Anwesenheit einer Königin, durch Schwärmen und den Auszug aus der Nisthöhle verstärkt.

Die sparsamste Erklärung der Verteilung der Wabennutzung bei der Speicherung von Honig und Nektar und der Anlage von Brutzellen ist ein selbstorganisierender Prozess, der keinen Gesamtplan im Gehirn der Honigbiene voraussetzt. Dieser Prozess konnte unter Annahme weniger einfacher, auf realen Untersuchungsergebnissen basierender Regeln mathematisch als voraussagungsfähiges Modell simuliert werden (figure 4).

Die Waben spielen in der Kommunikation innerhalb des Bienenvolkes eine besondere Rolle. Die Anwesenheit von Königinnenpheromon beeinflußt, ob, wo und zu welcher Zeit Königinnenzellen angelegt werden. Ebenso scheint die Verdeckelung der Brutzellen durch die Kombination eines Brutpheromons mit physikalischen Variablen wie dem Verhältnis 
der Größe der Larven zur Zellgröße gesteuert zu werden. Die Reparatur der Waben wird durch die Abwesenheit inhibitorischer Substanzen an den Zellenrändern stimuliert. Der Wabenduft wird durch das Wabenwachs übertragen und beeinflußt auch das Verteidigungsverhalten. Es ist eine interessante Entdeckung, daß der 'Tanzboden' der Sammelbienen chemisch definiert zu sein scheint.

Kürzlich konnte gezeigt werden, daß die Waben integraler Bestandteil der Vibrationskommunikation bei der Anwerbung von Sammlerinnen während des Schwänzeltanzes sind. In ähnlicher Weise erfolgt auch die Übertragung des Quakens der Königinnen durch die Waben. Wachs ist hierbei ein ideales Medium zur Weiterleitung von Vibrationen. Durch diese können zeitlich codierte Nachrichten schnell übertragen werden. Im Gegensatz zu Pheromonen, die eine lange Zeitkonstante haben, unterliegen Vibrationen einer raschen Abschwächung.

Zwischen Honigbienen und ihren Nestern bestehen eine Vielzahl reziproker Beziehungen, die sich über die Zeit in unterschiedlichen Geschwindigkeiten verändern. Da die gleichzeitige Verfolgung des Einflusses der bekannten Variablen zunehmend schwieriger wird, werden wir in Zukunft wahrscheinlich von der Anwendung der in der Konstruktion 'virtueller Realitäten' verwendeten mathematischen Techniken auf das Studium der Honigbienen profitieren. (C) Inra/DIB/ AGIB/Elsevier, Paris

\section{Apis mellifera / Waben / Pheromone / Schall / Selbstorganisation}

\section{REFERENCES}

Belic MR, Skarka V, Deneubourg JL, Lax M (1986) Mathematical model of honeycomb construction. J Math Biol 24, 437-449

Berg S (1996) Investigation to increase the attractiveness of the Malawi standard hive for natural colonisation through bee swarms. Dept National Parks and Wildlife, Rumphi, Malawi

Blum MS, Jones TH, Rinderer TE, Sylvester HA (1988) Oxygenated compounds in beeswax: identification and possible significance. Comp Biochem Phvsiol 91B, 581-583

Boch R (1979) Queen substance pheromone produced by immature queen honebees. I Apic Res $18,12-15$

Brand-Garnys EE, Sprenger J (1988) Bienenwachs - Neue Aspekte eines klassischen Kosmetikrohstoffs. Seifen Öle-Fette-Wachse 114, 547-552

Breed MD, Williams KR, Fewell JH ( 1988 a) Comb wax mediates the acquisition of nest-mate recognition cues in honey bees. Proc Natl Acad Sci USA 85, 8766-8769

Breed MD, Stiller TM, Moor MJ (1988b) The ontogeny of kin discrimination cues in the honey bee, Apis mellifera. Behav Genet 18, 439-448

Breed MD, Robinson GE, Page RE (1990) Division of labor during honey bee colony defense. Behav Ecol Sociobiol 27, 395-401

Budathoki K, Free JB (1986) Comb support and attachment within transitional beehives. J Apic Res 25, 87-99

Butler CG (1954) The World of the the Honeybee. Collins, London

Camazine S (1991) Self-organizing pattern formation on the combs of honey bee colonies. Behav Ecol Sociobiol 28, 61-76

Camazine S (1993) The regulation of pollen forage by honey bees: how foragers assess the colony's need for pollen. Behav Ecol Sociobiol 32 , 265-272

Chauvin R (1992) Le signal de reconstruction chez les abeilles; l'esprit de la ruche et les expériences de Darchen. CR Acad Sci Paris 314 (ser III), $361-363$

Collins AM, Rinderer TE (1985) Effect of empty comb on defensive behavior of honeybees. $J$ Chem Ecol 11,333-338

Crailsheim K, Stolberg E (1989) Influence of diet, age and colony condition upon intestinal proteolytic activity and size of the hypopharyngeal glands in the honeybee (Apis mellifera L.) $J$ Insect Physiol 35, 595-602

Darchen R (1968) Le rôle de la reine dans la construction cirière. In. Traité de biologie de l'abeille (R Chauvin, ed), vol 2, Masson et Cie, Paris, 305-321

Davidson BC, Hepburn HR (1986) Transformations of the acylglycerols in comb construction by honeybees. Naturwissenschaften 159, 73-74

Donhowe IG, Fennema O (1992) The effect of relative humidity gradient on water vapor permeance of lipid and lipid-hydrocolloid bilayer films. $J$ Am Oil Soc 69, 1081-1087

Engels W, Adler A, Rosenkranz P, Lübke G, Francke W (1993) Dose-dependent inhibition of emer- 
gency queen rearing by synthetic 9-0DA in the honey bee, Apis mellifica carnica. J Comp Physiol B 163, 363-366

Fell RD, Morse RA (1984) Emergency queen cell construction in the honeybee colony. Insectes Soc 32, 221-237

Fergusson LA, Free JB (1981) Factors determining the release of Nasanov pheromones at the hive entrance. Physiol Entomol 6, 15-19

Fergusson LA, Winston ML (1988) The influence of wax deprivation on temporal polyethism in honey bee (Apis mellifera L.) colonies. Can J Zool 66, 1997-2001

Francis BR, Blanton WE, Littlefield JL, Nunamaker RA (1989) Hydrocarbons of the cuticle and hemolymph of the adult honey bee (Hymenoptera: Apidae). Ann Entomol Soc Am $82,486-494$

Free JB (1987) Pheromones of Social Bees. Chapman and Hall, London

Goetz B, Koeniger N (1992) Structural features trigger capping of brood cells in honey bees. Apidologie 23, 211-216

Harbo JR (1988) Effect of comb size on population growth of honey bee (Hymenoptera: Apidae) colonies. J Econ Entomol 81, 1606-1610

Harbo JR (1993) Worker-bee crowding affects brood production, honey production, and longevity of honey bees (Hymenoptera: Apidae). J Econ Entomol 86, 1677-1678

Hepburn HR (1983) Comb construction by the African honeybee, Apis mellifera adansonii. $J$ Entomol Soc S Afr 46, 87-101

Hepburn HR (1986) Honeybees and Wax. Springer Verlag, Berlin

Hepburn HR (1988) Absconding in the African honeybee: the queen, engorgement and wax secretion. J Apic Res 27, 95-102

Hepburn HR, Kurstjens SP (1988) The combs of honeybees as composite materials. Apidologie $19,25-36$

Hepburn HR, Magnuson P (1988) Nectar storage in relation to wax secretion by honeybees. $J$ Apic Res 27, 90-94

Hepburn HR, Muller WJ (1988) Wax secretion in honeybees. Thermal integrity of the festoon. Naturwissenschaften 25, 628-629

Hepburn HR, Whiffler LA (1988) Dwarf and queenballs in swarms of the Cape honeybee. $S$ Afr $J$ Sci 84, 851-852

Hepburn HR, Whiffler LA (1991) Construction defects define patterns and methods in comb building by honeybees. Apidologie 22, 381-388

Hepburn HR, Nefdt RJC, Whiffler LA (1988) Queen loss in the Cape honeybee: the interactions of brood, laying workers (false queens?) and queen cells. S Afr J Sci 84, 778-780

Hepburn HR, Bernard RTF, Davidson BC, Muller WJ, Lloyd P, Kurstjens SP, Vincent SL (1991)
Synthesis and secretion of beeswax in honeybees. Apidologie 22, 21-36

Hillesheim E, Koeniger N, Moritz RFA (1989) Colony performance in honeybees (Apis mellifera capensis Esch) depends on the proportion of subordinate and dominant workers. Behav Ecol Sociobiol 24, 291-296

Jenkins MJ, Sneyd J, Camazine S, Murray JD (1992) On a simplified model for pattern formation in honey bee colonies. J Math Biol 30, 281-306

Juska A (1978) Temporal decline in attractiveness of honeybee queen tracks. Nature 276, 261

Kalmus H, Ribbands CR (1952) The origin of odors by which honey bees distinguish their companions. Proc R Soc B 140, 50-59

Kaminski LA, Slessor KN, Winston ML, Hay NW, Borden JH (1990) Honeybee response to queen mandibular pheromones in laboratory assays. $J$ Chem Ecol 16, 841-850

Kirchner WH (1993) Vibrational signals in the tremble dance of the honeybees, Apis mellifera. Behav Ecol Sociobiol 33, 169-172

Kurstjens SP, Hepburn HR, Schoning FRL, Davidson BC (1985) The conversion of wax scales into comb wax by African honeybees. J Comp Physiol $B$ 156, 95-102

Kurstjens SP, McClain E, Hepburn HR (1990) The proteins of beeswax. Naturwissenschaften 77 , 34-35

Le Conte Y, Arnold G, Trouiller J, Masson C (1990) Identification of a brood pheromone in honeybees. Naturwissenschaften 77, 334-336

Le Conte Y, Sreng L, Trouiller J (1994) The recognition of larvae by worker honeybees. Naturwissenschaften 81, 462-465

Le Conte Y, Sreng L, Poitout SH (1995a) Brood pheromone can modulate the feeding behavior of Apis mellifera workers (Hymenoptera: Apidae). J Econ Entomol 88, 798-804

Le Conte Y, Sreng L, Sacher N, Trouiller J, Dusticier G, Poitout SH (1995b) Chemical recognition of queen cells by honey bee workers Apis mellifera (Hymenoptera: Apidae). Chemoecology $5 / 6,6-12$

Lee PC, Winston ML (1985) The effect of swarm size and date of issue on comb construction in newly founded colonies of honeybees (Apis mellifera L.) Can J Zool 63, 524-527

Lensky Y, Slabezki Y (1981) The inhibiting effect of the queen bee (Apis mellifera L.) foot-print pheromones on the construction of swarming queen cups. J Insect Physiol 27, 313-323

Lensky Y, Cassier P (1992) Control of swarming by queen bee pheromones. BeeScience 2, 7-11

Lindauer M (1952) Ein Beitrag zur Frage der Arbeitsteilung im Bienenstaat. Z Vgl Physiol 34, 299-345

Liu TP (1989) Juvenile hormone III induced ultrastructural changes in the hypopharyngeal glands 
of honeybee Apis mellifera L. (Hymenoptera: Apidae) without and with infection by Nosema apis Zander (Microsporidae: Nosematidae). Int J Insect Morphol Embryol 18, 73-83

McNally LC, Schneider SS (1996) Spatial distribution and nesting biology of colonies of the African honey bee Apis mellifera scutellata (Hymenoptera: Apidae) in Botswana, Africa. Environ Entomol 25, 643-652

Michelsen A, Kirchner WH, Lindauer M (1986a) Sound and vibrational signals in the dance language of the honeybee, Apis mellifera. Behav Ecol Sociobiol 18, 207-212

Michelsen A, Kirchner WH, Andersen BB, Lindauer M (1986b) The tooting and quacking vibration signals of honeybee queens: a quantitative analysis. J Comp Physiol A 158, 605-611

Michelsen A, Andersen BB, Kirchner WH, Lindauer M (1989) Honeybees can be recruited by means of a mechanical model of a dancing bee. Naturwissenschaften 76, 277-280

Muller WJ, Hepburn HR (1992) Temporal and spatial patterns of wax secretion and related behavior in the division of labor of the honeybee (Apis mellifera capensis) J Comp Physiol 171, 111-115

Muller WJ, Hepburn HR (1994) Juvenile hormone III and wax secretion in honeybees (Apis mellifera capensis). J Insect Physiol 40, 873-881

Nachtigall W, Kresling B (1992) Bauformen der Natur. Teil II: Technische Biologie und Bionik von Platten- und Falt-Konstruktionen. Naturwissenschaften 99, 251-259

Naumann K, Winston ML, Slessor KN, Prestwich GD, Latli B (1992) Intra-nest transmission of aromatic honey bee queen mandibular gland pheromone components: movement as a unit. Can Entomol 124, 917-934

Nieh JC (1993) The stop signal of honey bees: reconsidering its message. Behav Ecol Sociobiol 33, $51-56$

Puleo SL (1991) Beeswax minor components: a new approach. Cosm \& Toil 106, 83-89

Rinderer TE, Hagstad WA (1984) The effect of empty comb on the proportion of foraging honeybees collecting nectar. J Apic Res 23, 80-81

Rösch GA (1927) Über die Bautätigkeit im Bienenvolk und das Alter der Baubienen. Weiterer Beitrag zur Frage nach der Arbeitsteilung im Bienenstaat. Z Vgl Physiol 6, 265-298

Sandeman DC, Tautz J, Lindauer M (1996) Transmission of vibration across honeycombs and its detection by bee leg receptors. J Exp Biol 199 , 2585-2594

Seeley TD (1992) The tremble dance of the honey bee: message and meaning. Behav Ecol Sociobiol 31, 375-383

Seeley TD (1995) The Wisdom of the Hive. Harvard University Press, Cambridge
Seeley TD, Fell RD (1981) Queen synthesis production in honeybee (Apis mellifera) colonies preparing to swarm (Hymenoptera: Apidae). $J$ Kans Entomol Soc 54, 192-196

Seeley TD, Morse RA (1976) The nest of the honeybee (Apis mellifera L.). Insectes Soc 23, 192-196

Seifert M, Haslinger E (1991) Über die Inhaltsstoffe der Propolis. Lieb Ann Chem 13, 93-97

Simpson J (1961) Nest climate regulation in honey bee colonies. Science 133, 1327-1333

Slessor KN, Kaminski LA, King GGS, Winston ML (1990) Semiochemicals of the honeybee queen mandibular glands. J Chem Ecol 16, 851-860

Southwick EE (1985) Thermal conductivity of wax comb and its effect on heat balance in colonial honey bees (Apis mellifera L.) Experientia 41, $1486-1487$

Szabo TI (1977) Effect of colony size and ambient temperature on comb building and sugar consumption. J Apic Res 16, 174-183

Taranov GF (1959) The production of wax in the honeybee colony. Bee World 40, 113-121

Tautz J (1996) Honey bee waggle dance: recruitment success depends on the dance floor. $J$ Exp Biol 199, 1375-1381

Tautz J, Lindauer M (1997) Honeybees establish specific sites on the comb for their waggle dances. J Comp Physiol A 180, 537-539

Tomas-Barberan FA, Ferreres F, Tomas-Lorente F (1993) Flavonoids from Apis mellifera beeswax. Z Naturforsch $48 \mathrm{c}, 68-72$

Trouiller J (1993) La communication chimique interet intra-spécifique chez l'abeille. Thesis, Université de Paris VII, Paris (cited from Le Conte et al, 1995)

Trouiller J, Arnold G, Le Conte Y, Masson C, Chappe B (1991) Temporal pheromonal and kairomonal secretion in the brood of honeybees. Naturwissenschaften 78, 368-370

Whiffler LA, Drusedau MUH, Crewe RM, Hepburn HR (1988) Defensive behavior and the division of labor in the African honeybee (Apis mellifera scutellata). J Comp Physiol A 163, 401-411

Whiffler LA, Hepburn HR (1991a) The queen in relation to wax secretion and comb building in honeybees. J Comp Physiol A 169, 209-214

Whiffler LA, Hepburn HR (1991b) Inhibition of queen cell construction in the Cape honeybee, Apis mellifera capensis. Apidologie 22, 229-236

Winston ML, Slessor KN, Willis LG, Naumann K, Higo HA, Wyborn MH, Kaminski LA (1989) The influence of queen mandibular pheromones on worker attraction to swarm clusters and inhibition of queen rearing in the honey bee (Apis mellifera L.) Insectes Soc 36, 15-27 